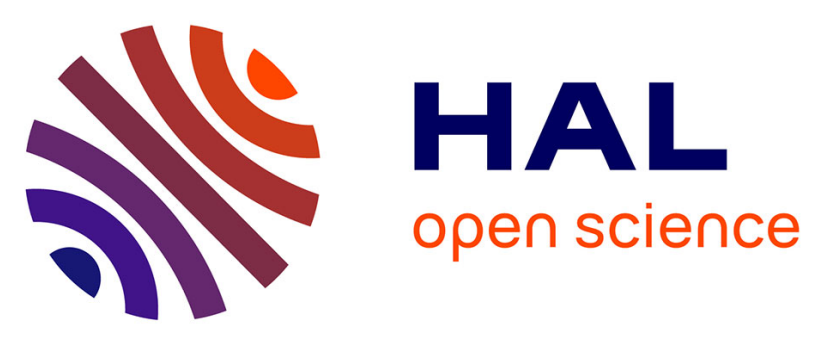

\title{
Short-term mild hyperglycemia enhances insulin-stimulated glucose disposal in lactating goats
}

Sophie Lemosquet, Elisabeth Debras, Michèle Balage, Jean-François J.-F. Hocquette, Henri Rulquin, Jean Grizard

\section{- To cite this version:}

Sophie Lemosquet, Elisabeth Debras, Michèle Balage, Jean-François J.-F. Hocquette, Henri Rulquin, et al.. Short-term mild hyperglycemia enhances insulin-stimulated glucose disposal in lactating goats. AJP - Regulatory, Integrative and Comparative Physiology, 2002, 282 (2), pp.R464-R474. hal02672620

\section{HAL Id: hal-02672620 \\ https://hal.inrae.fr/hal-02672620}

Submitted on 31 May 2020

HAL is a multi-disciplinary open access archive for the deposit and dissemination of scientific research documents, whether they are published or not. The documents may come from teaching and research institutions in France or abroad, or from public or private research centers.
L'archive ouverte pluridisciplinaire HAL, est destinée au dépôt et à la diffusion de documents scientifiques de niveau recherche, publiés ou non, émanant des établissements d'enseignement et de recherche français ou étrangers, des laboratoires publics ou privés. 


\section{Sophie Lemosquet, Elisabeth Debras, Michèle Balage, Jean François Hocquette, Henri Rulquin and Jean Grizard \\ Am J Physiol Regulatory Integrative Comp Physiol 282:464-474, 2002.}

You might find this additional information useful...

This article cites 46 articles, 23 of which you can access free at:

http://ajpregu.physiology.org/cgi/content/full/282/2/R464\#BIBL

Medline items on this article's topics can be found at http://highwire.stanford.edu/lists/artbytopic.dtl on the following topics:

Biochemistry .. Carbohydrate Regulation

Biochemistry .. Glucose Transport

Biochemistry .. Amino Acid Replacement

Medicine .. Hyperglycemia

Veterinary Science .. Dairy Cattle

Veterinary Science .. Goats

Updated information and services including high-resolution figures, can be found at:

http://ajpregu.physiology.org/cgi/content/full/282/2/R464

Additional material and information about American Journal of Physiology - Regulatory, Integrative and Comparative Physiology can be found at:

http://www.the-aps.org/publications/ajpregu

This information is current as of September 8, 2010 .

The American Journal of Physiology - Regulatory, Integrative and Comparative Physiology publishes original investigations that 


\title{
Short-term mild hyperglycemia enhances insulin- stimulated glucose disposal in lactating goats
}

\author{
SOPHIE LEMOSQUET, ${ }^{1}$ ELISABETH DEBRAS, ${ }^{2}$ MICHÈLE BALAGE, ${ }^{2}$ \\ JEAN FRANÇOIS HOCQUETTE,${ }^{3}$ HENRI RULQUIN, ${ }^{1}$ AND JEAN GRIZARD ${ }^{2}$ \\ ${ }^{1}$ Unité Mixte de Recherches sur la Production du Lait, Institut National de la \\ Recherche Agronomique, 35590 Saint Gilles; and ${ }^{2}$ Unité d'Etude du Métabolisme \\ Azoté and ${ }^{3}$ Unité de Recherches sur les Herbivores, Institut National de la Recherche \\ Agronomique, 63122 Saint Genès Champanelle, France
}

Received 8 February 2001; accepted in final form 26 September 2001

\begin{abstract}
Lemosquet, Sophie, Elisabeth Debras, Michèle Balage, Jean François Hocquette, Henri Rulquin, and Jean Grizard. Short-term mild hyperglycemia enhances insulin-stimulated glucose disposal in lactating goats. Am J Physiol Regulatory Integrative Comp Physiol 282: R464-R474, 2002.-This work was designed to study the effect of a 3-day mild hyperglycemia (5.3 vs. $3.3 \mathrm{mM}$ ) on the regulation of glucose metabolism in lactating goats. Glucose was intravenously infused at variable rates simultaneously with a constant potassium-amino acid infusion. Diet plus substrate infusion maintained net energy but not protein supply. Milk yield did not change. Skeletal muscle glucose transporter (GLUT-4) was analyzed before and after hyperglycemia. In addition, the acute effect of medium and high insulin doses on glucose turnover was measured in vivo during euglycemic and hyperglycemic hyperinsulinemic clamps under potassium and amino acid replacement. Hyperglycemia reduced the endogenous glucose appearance but increased glucose disposal. It decreased the total membraneassociated GLUT-4 protein in skeletal muscle. In contrast, it improved the acute insulin-stimulated glucose disposal. Both the level and duration (3 days) of hyperglycemia contributed to this improvement. We conclude that short-term mild hyperglycemia has similar effects in lactating goats as those already observed in nonlactating rodents or humans.
\end{abstract}

lactating ruminants; glucose turnover; amino acids

INSULIN AND GLUCOSE serve as important homeostatic regulators during lactation in ruminants. Insulin does not have any direct effect on the ruminant mammary gland $(34,43,52)$, but it regulates the supply of substrates to the mammary gland by altering peripheral extramammary metabolism. In this way, insulin stimulates anabolic process (e.g., lipogenesis and glycogenesis) and inhibits catabolic pathways (lipolysis, gluconeogenesis, ketogenesis, and proteolysis), thus preserving substrates for extensive use by the mammary gland. For example, the in vivo inhibition of proteolysis and the inhibition of glucose synthesis in response to insulin improve during lactation $(16,20$, $44,51)$. Glucose utilization may show either an in-

Address for reprint requests and other correspondence: S. Lemosquet, UMR Production du Lait, INRA, 35590 Saint Gilles, France (E-mail: lemosque@st-gilles.rennes.inra.fr). crease in sensitivity to insulin $(20,44)$ or a decrease (16). The latter may be explained partly by a decrease in the content of one form of glucose transporter (GLUT-4) in skeletal muscle (4). Insulin receptor number and affinity are apparently not modified (6).

The demand for glucose by the mammary gland can be partly met by the feeding of high-energy diets (9) or diets that increase the postrumen flow of starch (38). Increased postsplanchnic glucose supply leads to increased glycemia and insulinemia $(9,38)$. These responses, either separately or together, may result in the development of insulin resistance, as has been observed in sheep fed high-energy diets (9) and often in monogastric animals $(11,25)$. This insulin resistance could aid diversion of glucose to the mammary gland during lactation. It cannot be predicted from published data whether or not this insulin resistance appears in lactating ruminants. Rather, it has been demonstrated that short-term glucose infusion producing mild hyperglycemia improves insulin action in normal humans $(21,32)$ and rats (36). It has also been suggested that the tissue response to insulin was maintained over a 4-day insulin-glucose infusion in lactating cows. Unfortunately, the latter experiment was performed during euglycemia but not during mild hyperglycemia (43).

In view of this, we decided to analyze the effect of increased glucose supply on skeletal muscle GLUT-4 and the response of whole body glucose kinetics to insulin in lactating goats. For this purpose, blood glucose was maintained at a level higher $(\sim 5.5 \mathrm{mM})$ than the physiological range (2-4 $\mathrm{mM})$ for 3 days by an intravenous glucose infusion. Concomitant amino acid infusion was used to limit the interfering effect of glucose/insulin-induced hypoaminoacidemia. Indeed, it is recognized that hypoaminoacidemia stimulates peripheral glucose disposal (46) and can limit milk synthesis. Acute measurements of insulin action were performed before and after this 3-day experimental hyperglycemia using hyperinsulinemic clamps at medium and high insulin doses. Both euglycemic and

The costs of publication of this article were defrayed in part by the payment of page charges. The article must therefore be hereby marked "advertisement" in accordance with 18 U.S.C. Section 1734 solely to indicate this fact. 
hyperglycemic conditions were used at each time. Moreover, the amino acid infusion was adapted to limit the insulin-induced hypoaminoacidemia. With the use of such a protocol, it is therefore possible to determine the effects of both short-term (a few days) and acute hyperglycemia, as well as the consequent hyperinsulinemia, on the acute insulin action. Moreover, analysis of the data as a function of plasma insulin (doseresponse curves) allowed us to elucidate the specific effects of hyperglycemia in each case.

\section{MATERIALS AND METHODS}

\section{Animals and Management}

Six multiparous Alpine goats aged 4-8 yr were housed in individual stalls under natural lighting conditions. At the onset of the experiment, goats were at $80 \pm 1.5$ (mean $\pm \mathrm{SE}$ ) days postpartum and nonpregnant, weighing $56 \pm 5 \mathrm{~kg}$ and yielding $3.9 \pm 0.7 \mathrm{~kg} /$ day of milk. Goats were fed with a concentrate-roughage diet. Roughage was given ad libitum and consisted of chopped meadow hay and dehydrated Lucerne (1:1 on a dry matter basis) and provided (per kilogram of dry matter intake) $4.58 \mathrm{MJ}$ of net energy of lactation and 155 and $203 \mathrm{~g}$ of crude protein, respectively (30). A standard concentrate (Aliment Caprin Inra Ref. 281197, Moulin de Massagette; Rochefort-Montagne, France) was given in proportion to milk production with a maximal concentrate-toroughage ratio limited to $60: 40$ on a dry matter basis. On a dry matter basis, it contained $55 \%$ barley, $35 \%$ soybean meal, $5 \%$ beet molasses, and 5\% standard mineral premix for lactating ruminants (CMV 14/14, Ref. 3464, Moulin de Massagette) and provided $8.03 \mathrm{MJ}$ (per kilogram of dry matter) of net energy of lactation and $251 \mathrm{~g}$ of crude protein (30). To avoid intestinal glucose absorption, the concentrate contained only barley starch that could be completely fermented into volatile fatty acids in the rumen (30). Equal portions of roughage were offered at 9:00 AM and 5:00 PM daily. To minimize postprandial plasma insulin increase and plasma glucose decrease (38), four equal portions of concentrate were offered at 9:15 AM and 12:15, 3:15, and 6:15 PM daily. In addition, $15 \mathrm{~g}$ of sodium bicarbonate was given with concentrate at 9:15 AM. The goats had free access to water and mineral blocks (Agrolac Ref. 1893). Milking occurred at 8:30 $\mathrm{AM}$ and 4:30 PM.

\section{Surgery}

At least $1 \mathrm{wk}$ before the experiment began, each animal was surgically prepared for implantation of catheters in the right jugular vein and left carotid artery. General anesthesia was induced just before surgery and maintained during surgery with oxygen-isoflurane (1.5-2.5\%) using an appropriate mask (45). Polyvinyl chloride catheters (length, $500 \mathrm{~mm}$; inner diameter, $1.1 \mathrm{~mm}$; outer diameter, $1.9 \mathrm{~mm}$ ) were inserted as previously described (45). The catheters were held in position with sutures and tied to the skin of the neck. The whole procedure took no longer than $30 \mathrm{~min}$ and was carried out with little discomfort for the animals. The jugular vein catheter was used for infusions, and the carotid artery catheter was used for blood sampling.

\section{Experimental Procedures}

The protocol can be summarized in five major steps (Fig. 1). In step 1, the animals were studied under two conditions: control (C period) and after 3 days of hyperglycemia $(\mathrm{H}$ period) produced by intravenous glucose infusion with amino acids (Fig. 1). In step 2, a skeletal muscle biopsy was obtained
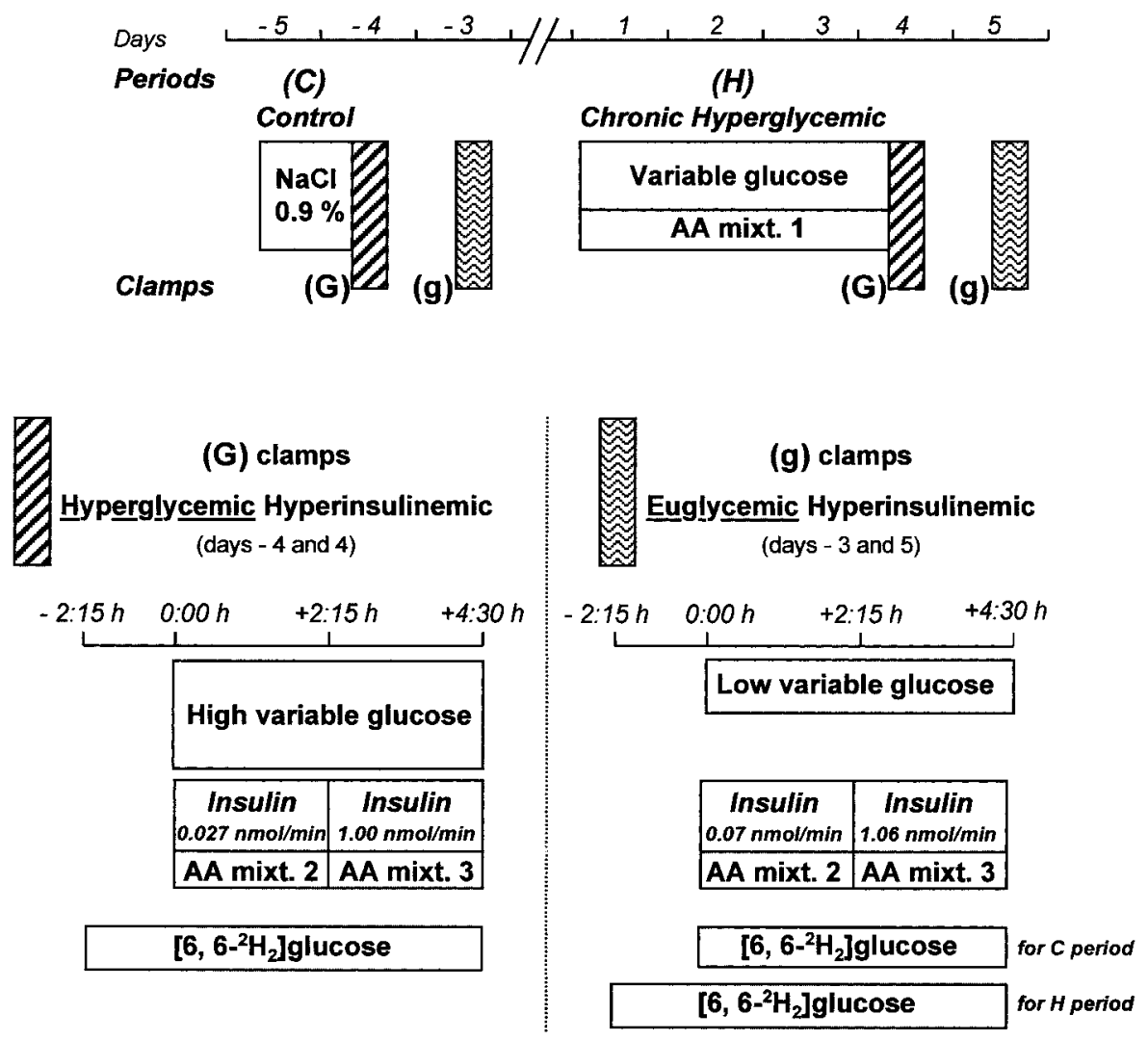

Fig. 1. Protocol of infusions. C, control period; $\mathrm{H}$, hyperglycemic period; AA mixt., amino acid mixture. 
during the $\mathrm{C}$ and $\mathrm{H}$ periods to analyze GLUT-4. In step 3, hyperinsulinemia ( $\mathrm{G}$ clamps: 4.5 -h duration) was also induced within both $\mathrm{C}$ and $\mathrm{H}$ periods to assess acute insulin action (Fig. 1). During the G clamps, glucose infusions were increased to maintain glycemia at $H$ levels ( $G$ clamps for hyperglycemic hyperinsulinemic clamps, see Fig. 1). In addition, amino acid and $\mathrm{K}^{+}$concentrations were stably maintained by appropriate infusions during all clamps. In step 4 , $24 \mathrm{~h}$ after $\mathrm{C}$ and $\mathrm{H}$ periods ceased, a repeat hyperinsulinemia test (g clamps) was initiated, but this time at the $\mathrm{C}$ glycemia level (g clamps for euglycemic hyperinsulinemic clamps, see Fig. 1). In step 5, measurements of glucose turnover rates were performed at the end of step 1 just before $\mathrm{G}$ or $\mathrm{g}$ clamps (from $-2: 15$ to $0: 00 \mathrm{~h}$ ) as well as during $\mathrm{g}$ and $\mathrm{G}$ clamps (from 0:00 to $4: 30 \mathrm{~h})$.

Step 1: $C$ and $H$ periods. Each goat first went through the $\mathrm{C}$ period (Fig. 1) with intravenous saline infusion $(154 \mathrm{mM}$ $\mathrm{NaCl}$, Bruneau Braun Medical; Boulogne, France). Saline was continuously infused by a Gilson peristaltic pump at a constant rate $(1.62 \pm 0.05 \mathrm{ml} / \mathrm{min})$ for $24 \mathrm{~h}$ beginning at 11:00 $\mathrm{AM}$ on day -5 . The animals were then subjected to a $72-\mathrm{h}$ period of experimental hyperglycemia ( $\mathrm{H}$ period) by continuous infusion of glucose (1.66 M, i.e., $30 \% \mathrm{vol} / \mathrm{wt}$ pyrogen free, Bruneau Braun Medical) beginning at 11:00 AM on day 1. The glucose infusion rate was adjusted to yield a constant and similar hyperglycemic state in all goats $(\sim 5.5 \mathrm{mM}$ during $\mathrm{H}$ period vs. $\sim 3 \mathrm{mM}$ during $\mathrm{C}$ period). This was performed empirically after rapid measurement of arterial glucose using a glucometer (assayed 2 min after blood sampling; Glucometer 3, Bayer Diagnostics; Puteaux, France). Previous experiments have shown that increasing the plasma insulin levels decreases plasma levels of potassium and free amino acids. To limit this decrease, a KCl-NaCl-amino acid mixture (AA mixture 1; Fig. 1) was continuously infused at a constant rate $(0.72 \pm 0.03 \mathrm{ml} / \mathrm{min})$ by another peristaltic pump. $A A$ mixture 1 contained (in $\mu \mathrm{mol} / \mathrm{ml}$ of saline) $93 \mathrm{KCl}, 154 \mathrm{NaCl}$, 1.75 Asp, 10.06 Thr, 0.246 Ser, 2.89 Glu, 1.50 Gly, 3.75 Ala, 21.03 Val, 0.161 Cys, 1.26 Met, 17.75 Ile, 37.52 Leu, 0.550 Tyr, 5.63 Phe, 30.03 Lys-HCl, 0.78 His-HCl, 16.63 Arg, 0.995 Pro, and 0.314 Trp. The rate of total liquid infused was $1.36 \pm 0.12,1.48 \pm 0.14$, and $1.49 \pm 0.15 \mathrm{ml} / \mathrm{min}$ during days 1, 2, and 3 of the $\mathrm{H}$ period, respectively. All arterial blood samples taken for glucometer analysis were centrifuged at $3,000 \mathrm{~g}$, and plasma samples were stored at $-20^{\circ} \mathrm{C}$ to be assayed for plasma glucose $(>12$ determinations per experimental day, most of them performed between 8:00 AM and 8:00 PM). In addition, four arterial blood samples were taken every day between 9:00 AM and 4:30 PM to assay plasma insulin, lactate, potassium, and free amino acid levels.

Step 2: muscle biopsies. GLUT-4 content was quantified in skeletal muscle biopsies. Muscle samples of the longissimus thoracis were obtained from one side of the spinal column on day -5 (C period) and from the other side on day 3 ( $\mathrm{H}$ period), both being taken at 3:00 PM. Biopsies were performed under local anesthesia after injection of $40 \mathrm{mg}$ xylocaine (Astra). Skin, derm, and aponevrosis were cut with a surgical blade (40), and two samples $(\sim 2 \times 200 \mathrm{mg})$ per biopsy were then extracted with a Wecester-Blake clamp (Climdal SA; Lyon, France). Samples were rinsed in saline, blotted, weighed, frozen in liquid nitrogen, and stored at $-80^{\circ} \mathrm{C}$ until analysis. After the sampling was completed, the wound was treated with penicillin G powder (Roussell Diamant; Paris, France), and the skin was closed up with clips and protected with an external preparation: Aluminisol (Sanofi Winthrop; Gentilly, France).

Step 3: G clamps. Hyperglycemic, hyperinsulinemic (G) clamps (Fig. 1) were performed immediately after muscle biopsies. The first clamp included a medium-insulin dose (between 0:00 and 2:15 h) followed by a high-insulin dose (between 2:15 and 4:30 h). Primed continuous infusions of insulin were performed using a Braun perfusor. Monocomponent human insulin (Actrapid, Novo; Copenhagen, Denmark) was dissolved in sterile saline supplemented with bovine serum albumin ( $1 \mathrm{~g} / 100 \mathrm{ml}$ A7888, Sigma; St. Louis, MO). The insulin concentration in the solutions (delivered at 0.103 $\mathrm{ml} / \mathrm{min}$ ) allowed insulin infusion rates at either 0.0270 or $1.00 \mathrm{nmol} / \mathrm{min}$. The initial boli of insulin injection were, respectively, 0.58 and $21.4 \mathrm{nmol}$ in $2.2 \mathrm{ml}$ pyrogen-free glucose saline mixtures (either $1.040 \mathrm{M}$ or $1.66 \mathrm{M}$ with medium and high insulin doses, respectively) and were infused by a peristaltic pump (Gilson) to maintain the arterial plasma glucose concentration $(\sim 5.5 \mathrm{mM})$. A bolus of the $1.66 \mathrm{M}$ glucose solution $(12.5 \mathrm{ml})$ was given to create the hyperglycemic state rapidly for the first clamp (medium insulin dose) performed immediately after the $\mathrm{C}$ period. A second glucose bolus dose $(6.4 \mathrm{ml})$ was injected for the high-insulin infusion. The glucose infusion rate was then adjusted empirically based on arterial blood glucose assayed every $10 \mathrm{~min}$. Another peristaltic pump delivered a KCl-NaCl-amino acid mixture [AA mixture 2 and $A A$ mixture 3 (Fig. 1) for medium insulin and high insulin doses, respectively] at a constant rate of $2.99 \pm 0.07 \mathrm{ml} / \mathrm{min}$. Both $A A$ mixture 2 and $A A$ mixture 3 contained $135 \mathrm{KCl}$ and $154 \mathrm{NaCl}$ (in $\mu \mathrm{mol} / \mathrm{ml}$ of saline). These mixtures contained (in $\mu \mathrm{mol} / \mathrm{ml}$ of saline) 0.662 and 3.86 Asp, 3.33 and 7.34 Thr, 0.122 and 1.77 Ser, 1.34 and $8.20 \mathrm{Glu}, 0.585$ and $8.24 \mathrm{Gly}, 1.17$ and $6.74 \mathrm{Ala}, 6.68$ and 11.67 Val, 0.054 and $0.458 \mathrm{Cys}, 0.342$ and 2.00 Met, 5.674 and 12.49 Ile, 11.01 and $18.98 \mathrm{Leu}, 0.211$ and 0.285 Tyr, 2.34 and 5.34 Phe, 10.00 and 13.34 Lys-HCl, 0.268 and 3.00 His-HCl, 5.75 and 12.65 Arg, 0.462 and 4.22 Pro, and 0.117 and 0.985 Trp, respectively. During the last 45-min period of each insulin infusion, arterial blood samples were taken to analyze plasma glucose levels ( 5 samples, every 10 min), plasma insulin levels, and glucose enrichments (3 samples, every $10 \mathrm{~min}$ ) as well as plasma lactate and free amino acid levels (2 samples, every $20 \mathrm{~min}$ ).

Step 4: g clamps. Euglycemic hyperinsulinemic (g) clamps were performed $24 \mathrm{~h}$ after G clamps (Fig. 1). The two protocols were similar except that plasma glucose was maintained at normal physiological levels for goats $(\sim 3 \mathrm{mM})$. To obtain similar plasma insulin concentration to the G clamps, higher insulin doses were required because basal insulin concentrations were lower than for the hyperglycemic state: 0.0715 and $1.063 \mathrm{nmol} / \mathrm{min}$ for medium and high insulin infusion rates, respectively. The primed insulin injections were 1.53 and $22.7 \mathrm{nmol}$ in $2.2 \mathrm{ml}$, respectively, and the concentrations of pyrogen-free glucose solutions were 0.53 and $1.040 \mathrm{M}$, respectively. In the case of the $\mathrm{g}$ clamps performed after the $\mathrm{C}$ period, $\left[6,6-{ }^{2} \mathrm{H}_{2}\right]$ glucose infusion did not begin $2: 15 \mathrm{~h}$ before the medium insulin infusion but took place at time 0 (Fig. 1).

Step 5. Glucose turnover rates were determined using [6,6- ${ }^{2} \mathrm{H}_{2}$ ]glucose (Fig. 1). A priming dose of $7.4 \mathrm{ml}$ of a $2.5 \mathrm{mM}$ solution in sterile saline was injected $2: 15 \mathrm{~h}$ before the end of the $\mathrm{C}$ and $\mathrm{H}$ periods (step 3). The $\left[6,6-{ }^{2} \mathrm{H}_{2}\right]$ glucose solution was then continuously infused at a constant rate $(0.036$ $\mathrm{mmol} / \mathrm{min}$ in sterile saline) using a Braun perfusor (Braun; Melsungen, Germany). To analyze the effect of insulin on glucose turnover rates, this infusion was prolonged during $\mathrm{G}$ clamps (0:00-4:30 h). Glucose enrichments were measured on the three blood samples taken every 10 min during the last 30-min period under each condition. The experiment was repeated $24 \mathrm{~h}$ later with the g clamps (step 4 ). 


\section{Analytic Methods}

All blood samples were collected into tubes containing heparin at a very low concentration $(2 \mathrm{IU} / \mathrm{ml})$ to avoid interference with the insulin radioimmunoassay performed according to Faverdin (1985) as quoted by Lemosquet et al. (38). Samples were kept on ice and immediately centrifuged at $2,500 \mathrm{~g}$ for $10 \mathrm{~min}$ at $4^{\circ} \mathrm{C}$. Plasma was aliquoted and stored at $-20^{\circ} \mathrm{C}$. Plasma glucose and lactate assays were performed on a Cobas analyzer (Roche; Neuilly-sur Seine, France) using enzymatic kits: D-glucose oxidase D-peroxidase (Unimate 7 Gluc PAP 073-6740, Roche; Neuilly, France) and lactate oxidase peroxidase (lactate PAP 610192, Biomerieux; Lyon, France), respectively. Plasma potassium was assayed by flame emission (PHF 90 apparatus with K filter, ISA Biologie; Cachan, France). Plasma insulin was determined by radioimmunoassay adapted to goat samples (52) with the INSI-PR kit (Cis Bio-International; Gif sur Yvettes, France). Plasma free amino acid concentrations were determined after deproteinization (with $50 \% \mathrm{vol} / \mathrm{vol}$ sulfosalicylic acid) according to the procedure described by Guinard et al. (24) and plasma tryptophan by a fluorometric procedure adapted to goat plasma samples (52).

To measure $\left[6,6{ }^{2} \mathrm{H}_{2}\right.$ ]glucose enrichments, plasma samples $(400 \mu \mathrm{l})$ were deproteinized with an equal volume of $1.2 \mathrm{M}$ perchloric acid and centrifuged. The supernatant was neutralized with $3.2 \mathrm{M} \mathrm{K}_{2} \mathrm{CO}_{3}$. After recentrifugation, the glucose fraction was extracted from the second supernatant by rapid sequential anion and cation exchange chromatography according to the procedure of Kreisberg et al. (33). The fraction containing glucose was dried before derivatization by boroacetylation (55). Sample $\left[6,6-{ }^{2} \mathrm{H}_{2}\right]$ glucose enrichments were determined by GC-MS (mass-selective detector 5972 coupled with a gas chromatograph 5890 series II, HewlettPackard; Les Ullis, France). The 297-to-299 ionic ratio responses were calculated in terms of isotopic enrichments using a standard curve made up from a known enrichment of glucose solutions. The total glucose turnover rate $(\mathrm{Q}$; in $\mathrm{mmol} / \mathrm{min}$ ) was determined by the equation

$$
\mathrm{Q}=\mathrm{F} \times \mathrm{IE}_{\mathrm{p}} / \mathrm{IE}_{\mathrm{inf}}
$$

where $\mathrm{F}$ is the $\left[6,6-{ }^{2} \mathrm{H}_{2}\right]$ glucose infusion rate (in $\mathrm{mmol} / \mathrm{min}$ ), $\mathrm{IE}_{\mathrm{inf}}$ is the isotopic enrichment of the infusate (i.e., $99 \mathrm{~mol} \%$ excess), and $\mathrm{IE}_{\mathrm{p}}$ (also in mol\% excess) is the plasma [6,6${ }^{2} \mathrm{H}_{2}$ ]glucose enrichment. The model generates the equation

$$
\mathrm{Q}=\mathrm{F}+\mathrm{I}+\mathrm{R}_{\mathrm{a}}=\mathrm{R}_{\mathrm{d}}
$$

where $I$ is the rate of intravenous unlabeled glucose infusion (zero in the basal state), $R_{a}$ is the endogenous glucose appearance, and $R_{d}$ is the glucose disposal from plasma. If $Q, F$, and $I$ are known, then $R_{d}$ and $R_{a}$ can be determined.

\section{GLUT-4 Protein Content Measurements}

The relative abundance of GLUT-4 was assayed by densitometric analysis of immunoblots of crude membrane preparation (4) from longissimus thoracis muscle samples. In brief, the resulting membrane pellet was suspended in $0.4 \mathrm{ml}$ Tris $\cdot \mathrm{HCl}$ buffer; $50 \mu \mathrm{l}$ were stored for protein assay by the Bradford method (kit 500-006, Bio-Rad; Ivry sur Seine, France), and the remainder was stored at $-80^{\circ} \mathrm{C}$. Equal amounts $(100 \mu \mathrm{g})$ of proteins from the crude membrane preparations were used for Western blot analysis. Immunoblotting was performed as previously described $(4,26)$ using a commercial polyclonal antibody raised against the $\mathrm{COOH}$ terminal sequence of rat GLUT-4 (Thr-Glu-Leu-Glu-Tyr-LeuGly-Pro-Asp-Gly-Asn-Asp) at a final dilution of 1:750. The
COOH-terminal sequence of goat GLUT-4 was found to be identical to that of rat GLUT-4 (1), indicating that this commercial antibody can be used in goats. A synthetic peptide of the COOH-terminal sequence of GLUT-4 was prepared by Neosystem Laboratoire (Strasbourg, France) and used to compete with the polyclonal antibody raised against rat GLUT-4. A horseradish peroxidase-labeled second antibody (anti-rabbit IgG, Tebu; Le Perray en Yvelines, France) was used at a final dilution of 1:10,000. To test the specificity of the detected bands, some blots were incubated with the first antibody against GLUT-4 (26) as well as with the synthesized peptide $(0.5 \mu \mathrm{g} / \mathrm{ml})$. The same procedure was also repeated with the rat muscle samples used as controls. As expected, the band corresponding to GLUT-4 was blunted by preabsorbing the primary antibody with the bovine peptide (Fig. 2). Furthermore, increasing amounts of crude protein membranes from longissimus thoracis preparations were analyzed by Western blot to verify the linear response between 0 and $200 \mu \mathrm{g}$ of protein (Fig. 3).

\section{Statistical Analysis}

To analyze data both during treatments ( $\mathrm{C}$ and $\mathrm{H}$ periods) and during clamps, three ANOVA were performed according to Winer et al. (56) using the general linear models procedure (PROC GLM) of SAS software. Because the $\mathrm{C}$ and $\mathrm{H}$ periods did not have the same duration, the first ANOVA was performed to compare parameters measured during day 1 of the $\mathrm{H}$ period and during the $\mathrm{C}$ period (1 day). The independent effects of periods and goats were assessed. The second ANOVA was performed to study the evolution of the response during the 3 days of the $\mathrm{H}$ period. A linear contrast was used to analyze this evolution between days according to Gill (22). The model included the effects of day and also of goat. The third ANOVA analyzed clamp results. The model included effects of period, goat, and insulin infusion rates during clamps, as well as the interactive effects of period $\times$ goat and period $\times$ insulin infusion rate. Period effects were then tested against the goat $\times$ period interaction according to Winer et al. (56). The residual mean square was used as the error term for other effects. For the three ANOVA, the assumption of normality of residual errors was tested using the ShapiroWilk statistical test included in the Univariate procedure of SAS software. When ANOVA detected a significant effect, means were compared using the Student's $t$-test with a sig-
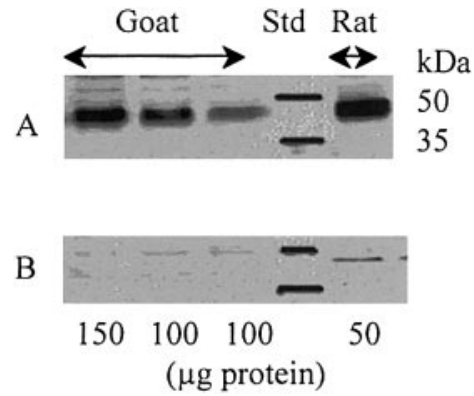

Fig. 2. Immunodetection of glucose transporter (GLUT-4) protein. Skeletal muscle crude membranes from rats and goats were prepared and analysed by two Western blot experiments. Autoradiograms show immunoreactive bands detected by enhanced chemiluminescence (ECL) reaction with the primary antibody alone $(A)$ and in presence of the synthetic peptide $(B)$. The same amounts of protein were used in $A$ and $B$, as indicated at the bottom of the autoradiograms. The position of immunoreactive bands was compared with molecular mass standards (Std). 

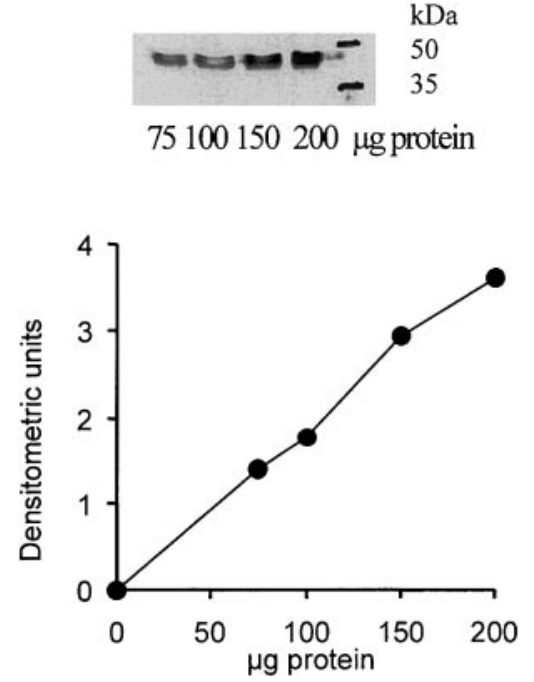

Fig. 3. Immunodetection of GLUT-4 protein in skeletal muscle from the lactating goat. Increasing amounts of protein from crude membrane preparation of the longissimus thoracis were analyzed by Western blot (top). The position of immunoreactive bands was compared with molecular new standards. Immunolabeled bands were quantified after ECL revelation by scanning densitometry (bottom). Results are expressed in densitometric units. GLUT-4 content was linearly related to the amount of protein loaded on the gel $(r=0.993$ with 4 measurements, $P<0.05$ ).

nificance level set at a value of 0.05 . Results are given as means with the corresponding SE of the ANOVA.

\section{RESULTS}

\section{Feed Intake and Milk Yield}

During the $\mathrm{C}$ period, goats ate $2,229 \pm 264 \mathrm{~g}$ of dry matter. This level of intake provided an average amount $14.2 \pm 2.1 \mathrm{MJ} /$ day of net energy for lactation (30) and $270 \pm 18 \mathrm{~g} /$ day of protein digested in the small intestine (PDI). Goats were near equilibrium for net energy $(-1.2 \pm 1.8 \mathrm{MJ})$ and protein balances $(+49 \pm$ $32 \mathrm{~g}$ of PDI; see recommendations in Ref. 28). Dry matter intake decreased linearly during the $\mathrm{H}$ period $(2,229 \mathrm{~g}$ on day $1,1,890 \mathrm{~g}$ on day 2 , and $1,563 \mathrm{~g}$ on day
3 , linear effect $\mathrm{SE}=286 \mathrm{~g}, P<0.01)$. However, feed intake plus substrate intravenous infusions (38) provided similar amounts of net energy $(16.3 \pm 1.5 \mathrm{MJ} /$ day) during the $\mathrm{C}$ period (feed intake plus saline infusion) and during the $\mathrm{H}$ period (feed intake plus glucose infusion). In contrast, protein supply decreased linearly during the $\mathrm{H}$ period $(268,239$, and $212 \mathrm{~g}$ of PDI on days 1,2, and 3, respectively, linear effect: $\mathrm{SE}=$ $51.5 \mathrm{~g}, P<0.01)$. Despite the reduction in feed intake, goats were in equilibrium both for net energy (average of 3 days: $+0.51 \pm 0.47 \mathrm{MJ} /$ day) and protein balances $(+24 \pm 29 \mathrm{~g} /$ day of PDI). The milk and protein yields were not affected by the $\mathrm{H}$ period (average of 3 days: $3.87 \pm 0.23$ and $102 \pm 10 \mathrm{~g} /$ day, respectively, compared with $3.79 \pm 0.23$ and $105 \pm 10$ g/day during the $\mathrm{C}$ period).

\section{Arterial Plasma Insulin}

Plasma insulin was significantly higher during day 1 of the $\mathrm{H}$ period than during the $\mathrm{C}$ period $(0.20$ vs. 0.08 $\mathrm{nmol} / \mathrm{l}, \mathrm{SE}=0.06 \mathrm{nmol} / 1, P<0.05)$. It then increased linearly during the 3 days of the $\mathrm{H}$ period $(0.27$ and $0.33 \mathrm{nmol} / \mathrm{l}$, linear effect: $\mathrm{SE}=0.06 \mathrm{nmol} / \mathrm{l}, P<0.001$ ). During each clamp study, insulin infusion resulted in stable hyperinsulinemia during the last 45 -min period. The mean coefficients of variation for plasma insulin over this period ranged between $6 \%$ and $14 \%$. During G clamps performed after the $\mathrm{H}$ period, the high insulin infusion rate led to significantly higher plasma insulin concentrations than after the $\mathrm{C}$ period (Table 1). This was presumably a reflection of the higher basal plasma insulin after the 3-day hyperglycemia. In all other cases, similar insulin infusions yielded similar plateau insulin levels.

\section{Arterial Plasma Glucose and Glucose Infusion Rates}

As expected, arterial plasma glucose concentrations were significantly higher during day 1 of the $\mathrm{H}$ period $(5.41 \pm 0.66 \mathrm{mM})$ than during the $\mathrm{C}$ period $(3.47 \pm 0.66$ $\mathrm{mM}, P<0.05)$. It remained constant during the 3 days of the $\mathrm{H}$ period (5.14 and $5.53 \mathrm{mM}$ on days 2 and 3 ,

Table 1. Arterial plasma insulin, glucose, and lactate concentrations and glucose infusion rates during clamps

\begin{tabular}{|c|c|c|c|c|c|c|c|c|}
\hline \multirow[b]{2}{*}{ Hyperglycemic hyperinsulinemic clamps } & \multicolumn{3}{|c|}{ Control Period } & \multicolumn{3}{|c|}{ Hyperglycemic Period } & \multirow[t]{2}{*}{$\mathrm{SE}$} & \multirow[t]{2}{*}{$\begin{array}{c}\text { Sign } \\
\text { Effects }\end{array}$} \\
\hline & & & & & & & & \\
\hline Insulin infusion, $\mathrm{nmol} / \mathrm{min}$ & 0 & 0.027 & 1.00 & 0 & 0.027 & 1.00 & & \\
\hline Plasma glucose, $\mathrm{mM}$ & $3.23 \dagger$ & $5.74 \ddagger$ & $5.08 \S$ & $5.60^{*}$ & 5.69 & 5.55 & 0.52 & Gly, Ins \\
\hline Glucose infusion, $\mathrm{mmol} / \mathrm{min}$ & $0 \dagger$ & $0.81 \dagger$ & $1.28 \S$ & $1.58^{* \dagger}$ & $1.37 * \dagger$ & $2.16 *+$ & 0.21 & Gly, Ins \\
\hline Plasma lactate, $\mathrm{mM}$ & 0.26 & 0.26 & 0.33 & $0.34 \dagger$ & $0.39 * \dagger$ & $0.52 *$ & 0.08 & Gly, Ins \\
\hline Plasma insulin, $\mathrm{nM}$ & $0.05 \dagger$ & $0.14 \dagger$ & $0.99 \ddagger$ & $0.05 \dagger$ & $0.14 \dagger$ & $1.10 \ddagger$ & 0.17 & Ins \\
\hline Plasma glucose, mM & $2.99 \dagger$ & $3.34 \ddagger$ & $3.10 \ddagger$ & $2.79 \dagger$ & $3.32 \ddagger$ & $3.23 \%$ & 0.24 & Ins \\
\hline Glucose infusion, $\mathrm{mmol} / \mathrm{min}$ & $0 \dagger$ & $0.56 \ddagger$ & $1.20 \ddagger$ & $0 \dagger$ & $0.77^{*+}$ & $1.63 * \S$ & 0.14 & Gly, Ins \\
\hline Plasma lactate, mM & $0.31 \dagger$ & $0.20 \ddagger$ & $0.24 \dagger+$ & 0.33 & 0.26 & $0.35^{*}$ & 0.07 & Gly, Ins \\
\hline
\end{tabular}

Values are means with SE of ANOVA; $n=6$. Data were analyzed to compare the chronic hyperglycemic period to the control period (Gly) and the effect of insulin infusion rates (Ins). *Values obtained after the chronic hyperglycemic period were significantly different from the corresponding values obtained after the control period. $\dagger, \ddagger, \S$ For each period, values not followed by the same superscript are significantly different. The significance level was set at $P<0.05$. 
respectively, $\mathrm{SE}=0.43 \mathrm{mM})$. This was achieved by adaptation of the glucose infusion rates $(1.05,1.28$, and $1.28 \mathrm{mmol} / \mathrm{min}$ on days 1,2 , and 3 , respectively; 1.58 $\mathrm{mmol} / \mathrm{min}$ at the beginning of day 4 ).

Just before the clamps (during the 2:15 $\mathrm{h}$ before insulin infusion), plasma glucose values were similar to those found in samples used to characterize the $\mathrm{C}$ and $\mathrm{H}$ periods (Table 1). During the last 45-min period of each clamp, plasma glucose was maintained at a steady state (mean coefficients of variation ranged between $3.5 \%$ and $7 \%$ ). As expected, the G clamps were always performed under the same glycemia as during the $\mathrm{H}$ period and the $\mathrm{g}$ clamps were always performed under the same glycemia as during the $\mathrm{C}$ period (Table 1 ).

The glucose infusion rate was at a steady state during the last 45-min period of each clamp (mean coefficients of variation ranging between $3.6 \%$ and $10.4 \%$ ). In all cases, the clamps with the high insulin level needed higher glucose infusion rates than the clamps with the medium insulin level $(P<0.001)$. The glucose infusion rate was always higher after the $\mathrm{H}$ period than after the $\mathrm{C}$ period $(P<0.001)$.

\section{Arterial Plasma Lactate}

Plasma lactate exhibited similar values on day 1 of the $\mathrm{H}$ period and in the $\mathrm{C}$ period $(0.35$ and $0.33 \mathrm{mM}$, $\mathrm{SE}=0.06 \mathrm{mM})$. It did not increase during days 2 and 3 of the $\mathrm{H}$ period $(0.49$ and $0.41 \mathrm{mM}, \mathrm{SE}=0.15 \mathrm{mM})$. Plasma lactate concentration was at a steady state during the clamp studies. Mean values recorded before insulin infusions were consistent (Table 1) with those previously observed (see above). Plasma lactate increased at the high insulin infusion rate during $G$ clamps performed after the $\mathrm{H}$ period (Table 1). It was higher after the $\mathrm{H}$ period than after the $\mathrm{C}$ period $(P<$ 0.05 ) at both insulin infusion rates during $\mathrm{G}$ clamps and only at the high insulin infusion rate during $\mathrm{g}$ clamps $(P<0.01)$.

\section{Arterial Plasma Potassium}

Plasma potassium was not significantly modified by any treatment. It was similar on day 1 of the $\mathrm{H}$ and $\mathrm{C}$ periods (3.68 and $3.80 \mathrm{meq} / \mathrm{l}$, respectively, $\mathrm{SE}=0.15$ meq/l) and remained constant on days 2 and 3 of the $\mathrm{H}$ period $(3.90$ and $3.87 \mathrm{meq} / \mathrm{l}, \mathrm{SE}=0.11 \mathrm{meq} / \mathrm{l}$ for 3 days). It also remained constant during all the clamps (means ranging between 4.01 and $4.20 \mathrm{meq} / \mathrm{l}$ and coefficients of variation ranging between $5.6 \%$ and $6.7 \%$ ).

\section{Arterial Plasma Free Amino Acids}

Plasma free Phe and Try showed no change during the $\mathrm{H}$ period compared with the $\mathrm{C}$ period (Fig. 4). In contrast, Arg, Lys, Leu, Ile, Val, Thr, His, and Met levels decreased significantly. This decrease began on day 1 with Ile and His but only on days 2 or 3 with the other amino acids. The sum of the semiessential (Tyr) and nonessential amino acids (Ala, Asp, Gly, Glu, and Ser) was not affected by the 3-day $\mathrm{H}$ period $(929,1,036$, and $986 \mu \mathrm{M}$ on days 1,2, and 3 during the $\mathrm{H}$ period, $\mathrm{SE}=96$ vs. $994 \pm 84 \mu \mathrm{M}$ during the $\mathrm{C}$ period).

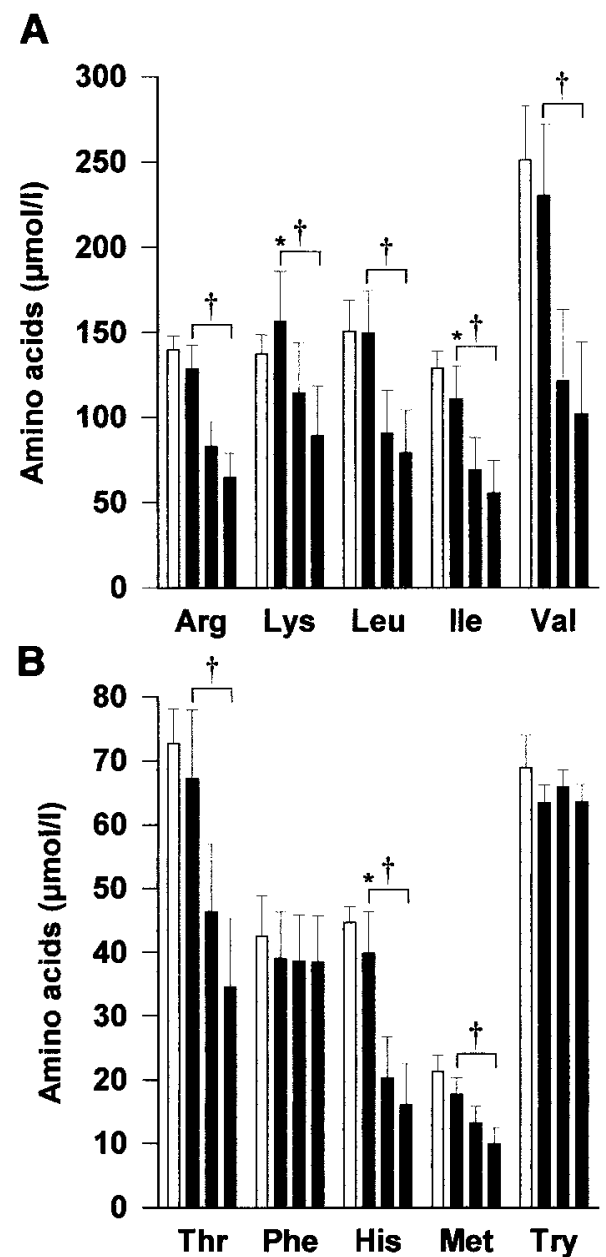

Fig. 4. Plasma levels of free essential amino acids during the control period (open bars) and the 3 consecutive days of the chronic hyperglycemic period (solid bars). Values are means $\pm \mathrm{SE}$ of the statistical model. $* P<0.05$, control day vs. day 1 of the hyperglycemic period; $\dagger P<0.05$, linear decrease during the 3 days of the hyperglycemic period.

Plasma free amino acids were at a steady state during the clamp studies. Most amino acids exhibited the same levels just before G clamps (day -4 or day 4 between $-2: 15$ and 0:00 $\mathrm{h}$ in Fig. 1) than the corresponding previous day (day -5 for the $\mathrm{C}$ period or day 3 for the $\mathrm{H}$ period). They were only slightly modified during the insulin infusions during clamps for both periods $(\mathrm{C}$ or $\mathrm{H})$. In other words, the $\mathrm{G}$ clamps were performed under conditions of normal amino acid levels after the $\mathrm{C}$ period but under conditions of hypoaminoacidemia after the $\mathrm{H}$ period. The g clamps were also performed under normal aminoacidemia after the $\mathrm{C}$ period. This was not exactly the case for the g clamps after the $\mathrm{H}$ period, because branched-chain amino acids (Leu, Ile, and Val) and Arg and Lys stayed at low levels. At the same time, the sum of semiessential and nonessential amino acids exhibited high values.

\section{Glucose Turnover}

Plasma glucose enrichments were at a steady state (see the coefficients of variation in Table 2). The kinet- 
Table 2. $\left[6,6-{ }^{2} \mathrm{H}_{2}\right]$ glucose infusion rates, plasma glucose enrichments, and glucose fluxes

\begin{tabular}{llllll}
\hline \hline & & & & \\
& & & Hyperglycemic Period & SE \\
Effects
\end{tabular}

ics measurements just before $\mathrm{G}$ clamps indicate that the $\mathrm{H}$ period led to a marked increase in whole body glucose disposal $\left(R_{d}: 1.98\right.$ vs. $1.00 \mathrm{mmol} / \mathrm{min}$ for the $\mathrm{H}$ and $\mathrm{C}$ periods, respectively, $\mathrm{SE}=0.18 \mathrm{mmol} / \mathrm{min}, P<$ 0.01). During the clamps, increasing the insulin infusion rate from medium to high led to increased $R_{d}$ (Fig. 5); except for g clamps, statistically significant variations were achieved after the $\mathrm{H}$ period (Table 2). Whatever the insulin infusion rate, $R_{d}$ of $G$ clamps was higher after the $\mathrm{H}$ period than after the $\mathrm{C}$ period $(+0.28$ and $+0.69 \mathrm{mmol} / \mathrm{min}$ at medium and high insulin, respectively, $P<0.05)$. This was also the case for the $\mathrm{g}$ clamps with high insulin infusion $(+0.36 \mathrm{mmol} /$ min, $P<0.05)$. These differences between the $\mathrm{H}$ and $\mathrm{C}$

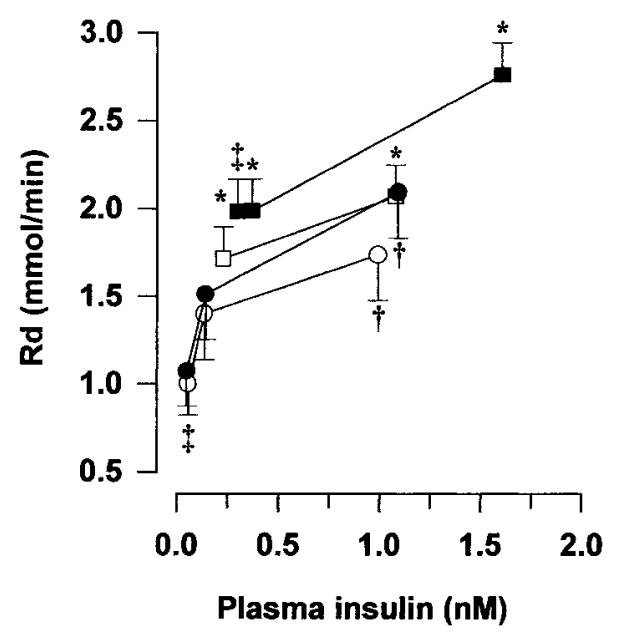

Fig. 5. Glucose disappearance rate $\left(R_{d}\right)$ in response to increasing plasma insulin levels. The open symbols indicated clamps performed after the control period, and the filled symbols indicate clamps performed after the chronic hyperglycemic period. The circles are the euglycemic conditions and the squares are the hyperglycemic ones. Values are means $\pm \mathrm{SE}$ of the ANOVA. $* P<0.05, \square$ vs. $\square ; \uparrow P<0.05$, $\bigcirc$ vs. $\bullet ; P<0.05$, end of the chronic hyperglycemic period vs. end of the control period ( $2: 15 \mathrm{~h}$ before the hyperglycemic clamps). periods were maintained when the glucose disposal was expressed in terms of the metabolic clearance rate (data not shown). During each period, $R_{d}$ was higher with $\mathrm{G}$ clamps than with g clamps $(+0.31$ and +0.34 $\mathrm{mmol} / \mathrm{min}$ during the $\mathrm{C}$ period at medium and high insulin, respectively; +0.48 and $+0.67 \mathrm{mmol} / \mathrm{min}$ during the $\mathrm{H}$ period, all $P<0.05$ ). Dose-response curves of the effect of insulin on $R_{d}$ can be drawn if we include the $R_{d}$ value obtained before insulin infusion (Fig. 5). On the basis of these curves, it appears that the $R_{d}$ values observed at a similar insulinemia were significantly higher either during acute or after short-term hyperglycemia. In other words, each glycemic condition produces a specific dose-response curve. Note that the difference of $R_{d}$ between curves for $G$ and $g$ clamps was approximately constant at $\sim 0.3 \mathrm{mmol} / \mathrm{min}$ (Table 2 ).

The $R_{\mathrm{a}}$ was significantly reduced at the end of the $H$ period compared with the $\mathrm{C}$ period $(0.41 \mathrm{vs} .1 .00 \mathrm{mmol} /$ min, $\mathrm{SE}=0.19, P<0.001$; see Table 2 ). The maximum decrease occurred during $\mathrm{G}$ clamps after the $\mathrm{H}$ period. It decreased linearly with increasing insulin infusion during g clamps. During medium insulin infusion during $\mathrm{G}$ clamps, $\mathrm{R}_{\mathrm{a}}$ was lower during the $\mathrm{H}$ period than during the $\mathrm{C}$ period.

\section{GLUT-4 Content in Muscle}

As expected, total protein content of muscle did not differ significantly between the $\mathrm{H}$ and $\mathrm{C}$ periods (Fig. 2 ). In addition, protein recoveries in crude membrane preparations from longissimus thoracis muscle biopsies were similar whatever the period $(4.68 \pm 0.37$ and $4.62 \pm 0.20 \mathrm{mg} / \mathrm{g}$ tissue wet wt, i.e., $2.31 \%$ and $2.34 \%$ of protein in the starting homogenate after the $\mathrm{C}$ and $\mathrm{H}$ periods, respectively). Consistent with our previous study (4), a $\sim 45$ - to $50-\mathrm{kDa}$ immunoreactive major protein band was detected on Western blots of each muscle preparation. The GLUT-4 protein content de- 

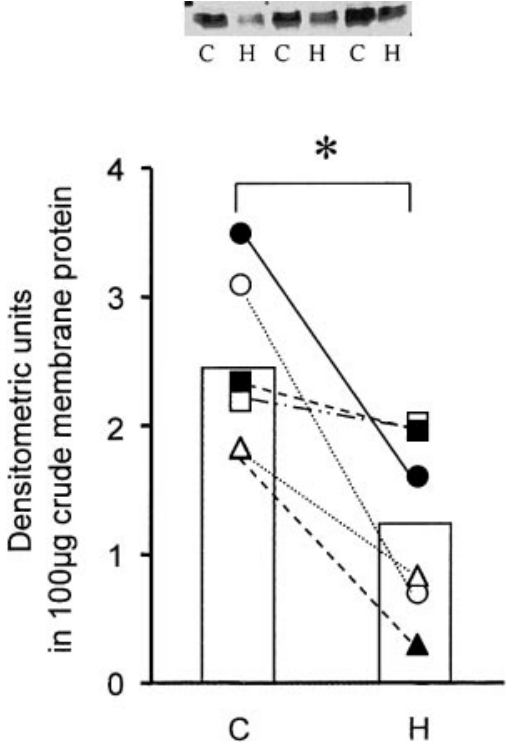

Fig. 6. Quantification of GLUT-4 content in crude membranes of the longissimus thoracis from 6 goats during the control (C) and chronic hyperglycemic $(\mathrm{H})$ periods. Crude membrane preparations were analyzed by Western blot. Immunolabeled bands were quantified after ECL revelation by scanning densitometry (bottom). Results are expressed in arbitrary units per $100 \mu \mathrm{g}$ protein in crude membrane. Each symbol represents an individual goat. The means are given by open bars. ${ }^{*} P<0.05$. Representative autoradiograms are also presented $(t o p)$.

creased significantly (Fig. 6) after the $\mathrm{H}$ period compared with the $\mathrm{C}$ period $(-50.1 \%, P<0.03)$.

\section{DISCUSSION}

Our experiment demonstrated that the increased glucose disposal in dairy goats under short-term mild hyperglycemia is due to the hyperinsulinemia but also to the improvement of insulin action. Both hyperglycemia as such and the duration of exposure (3 days) contributed to this improvement. Indeed, dose-response curves showed that, at the same insulin level, acute hyperglycemia increased the insulin-stimulated glucose disposal whatever the period (before and after the 3-day mild hyperglycemic period). The acute effect of insulin on glucose disposal was also improved after the 3-day mild hyperglycemia whatever the glycemic levels during the measurements of insulin action (euglycemic or hyperglycemic hyperinsulinemic clamps). Our results are consistent with data from human or monogastric mammals subjected to mild hyperglycemia (5-10 $\mathrm{mM}$ ) for relatively short periods, where sensitivity to insulin was improved $(21,32,36)$. However, these previous studies did not allow us to determine the respective effects of acute (few hours) and short-term (few days) glucose supply.

It is still not known whether this enhanced insulin sensitivity originates from hyperglycemia as such or the associated hyperinsulinemia. Short-term hyperinsulinemia obtained by insulin infusion in rats and humans increased the action of insulin whatever the level of glycemia $(53,54)$. In keeping with this, an increase in insulin sensitivity has been observed in hyperinsulinemic obese rodents at the beginning of the syndrome (37). However, 3- or 4-day hyperinsulinemic euglycemic clamp studies have revealed that hyperinsulinemia alone is not sufficient to explain fully the increase in insulin action in lactating ruminants $(5,43)$.

It has been demonstrated that the insulin-stimulated glucose utilization is increased when clamp studies are performed under conditions of hypoaminoacidemia (46). This phenomenon might explain the improved insulin action under short-term hyperglycemia because levels of most essential plasma free amino acids decreased during this period despite the intravenous amino acid infusion (AA mixture 1). Plasma free amino acids were maintained during $\mathrm{G}$ clamps at their levels just before insulin infusion, i.e., under conditions of normal aminoacidemia during the control period and under conditions of hypoaminoacidemia after shortterm hyperglycemia. Such a condition is therefore consistent with an increase in the insulin-stimulated glucose utilization. However, this mechanism should be considered with caution because this improvement was persistent during $\mathrm{g}$ clamps despite the fact that the hypoaminoacidemia was partly prevented. Moreover, the $\mathrm{G}$ clamps were performed under lower free fatty acid (FFA) levels during the $\mathrm{H}$ period than during the $\mathrm{C}$ period (102 vs. $593 \mu \mathrm{eq} / \mathrm{l}$ in the absence of exogenous insulin, $103 \mathrm{vs.} 202 \mu \mathrm{eq} / \mathrm{l}$ at medium insulin, and $64 \mathrm{vs}$. $154 \mu \mathrm{eq} / \mathrm{l}$ at high insulin, $\mathrm{SE}=79 \mu \mathrm{eq} / \mathrm{l}$, all $P<0.05$ ). It is well established that a decrease in FFA stimulates glucose uptake during euglycemic hyperinsulinemic clamps (48). In contrast, increased concentrations of FFA induce insulin resistance (18). The mechanisms that underlie these FFA-induced abnormalities in glucose metabolism have been widely discussed (e.g., FFAdependent changes in glucose transport/phospohorylation activity through effects on the insulin signaling cascade) $(10,18)$. Unfortunately, FFA did not show a significant decrease during $\mathrm{g}$ clamps and therefore could not be involved in the improvement in insulin action during these clamps. It is generally accepted that glucose transport is the rate-limiting step of insulin-mediated glucose uptake in skeletal muscle and adipose tissue. Although quantitatively less important than muscle tissue, intramuscular adipose tissue might account for a small part of the insulin-stimulated glucose utilization, whereas other fatty tissues use acetate as fat precursors in ruminants (for a review, see Ref. 27). However, in midlactating goats, intramuscular adipose tissue is probably quantitatively negligible compared with muscle fibers because high-producing goats used body energy reserves to meet their requirements at the beginning of lactation (8). In favor of this hypothesis, we were not able to take any subcutaneous adipose tissue by biopsy in this experiment because the lactating goats were too thin.

Surprisingly, the increased insulin action on glucose disposal after 3-day mild hyperglycemia occurred along with a decreased GLUT-4 protein content in white glycolytic skeletal muscle. This suggests an increase in the activity of the GLUT-4 proteins or a change in GLUT-4 subcellular localization. It is still an open 
question whether the studied muscle is representative of the whole muscle mass for GLUT-4 content analysis. Such a discrepancy has been already observed in fasted rats between variations in crude protein GLUT-4 content and variations in vivo insulin-stimulated glucose uptake (14). Whether or not this decrease in GLUT-4 content could originate from hyperglycemia alone or from the associated hyperinsulinemia has to be considered. Short-term hyperglycemia rapidly reduced the plasma membrane GLUT-4 content $(41,42)$, although no effect could be detected in crude muscle membrane (47). Long-term hyperglycemia is able to regulate the expression of skeletal muscle GLUT-4. For example, it has been shown that GLUT-4 mRNA is decreased in skeletal muscle of long-term diabetic rats and that insulin treatment for $1 \mathrm{wk}$ produces an increase of this mRNA $(12,31)$. The correction of hyperglycemia in diabetic rats by vanadate or phlorizin treatment also resulted in an increase in GLUT-4 mRNA and protein in skeletal muscle $(17,49)$. In contrast, insulin is usually not a prime short-term regulator of total GLUT-4 protein in skeletal muscle in goats (5) and rats $(17,25$, 47) maintained in euglycemic conditions. Our experiments did not allow us to distinguish plasma-associated GLUT-4 from intracellular membrane-associated GLUT-4 because crude membrane preparations represent total cellular membranes (3). Factors other than the abundance of GLUT-4 therefore may play a role in determining insulin-stimulated glucose uptake in goats. We may speculate that the improved glucose utilization under hyperinsulinemia observed in goats after short-term mild hyperglycemia results from the translocation of GLUT-4 protein by the associated hyperinsulinemia. Indeed, it has been well established that acute insulin stimulation of glucose transport activity occurs primarily through the recruitment of GLUT-4 protein from an intracellular pool at the cell surface.

According to an increase in the action of insulin on skeletal muscle glucose disposal after short-term mild hyperglycemia, plasma lactate concentration under insulin infusion was more often higher during the $\mathrm{H}$ period than during the $\mathrm{C}$ period. Indeed, it is now recognized that increased plasma lactate concentration with insulin concentration is due mainly to enhanced lactate production from glucose. It is unlikely that a decreased hepatic lactate uptake could explain an increase of plasma lactate concentration because the gluconeogenesis from lactate is very low in hepatocytes derived from fed ruminants compared with nonruminant animals [see discussion in Tauveron et al. (50)]. As we have previously observed in lactating goats, the increase in plasma lactate concentration was only visible at high insulin levels (50). Unfortunately, during our experiment, we did not measure the other insulindependent fates of glucose in skeletal muscles, e.g., storage of glycogen and oxidative pathways.

The experimental hyperglycemia not only increased efficiency of insulin effects but also seemed to increase insulin secretion. The ratio between plasma insulin and plasma glucose greatly increased during the hy- perglycemic period (37, 52 , and 59 on days 1,2 , and 3 during the $\mathrm{H}$ period vs. 23 during the $\mathrm{C}$ period, $10^{-3}$ ). This increase strongly suggests an improvement of insulin secretion because the insulin metabolic clearance rate was not significantly modified. Indeed, similar insulin infusion rates during the clamp studies yielded the same increases in plasma insulin above the basal values. However, this ignores the possible inhibition of endogenous insulin secretion by exogenous insulin. An improving effect on insulin secretion has already been measured in monogastric mammals in mild degrees of hyperglycemia $(11,36)$. In the present experiment, increasing both the insulin secretion and insulin efficiency during hyperglycemia should further improve the glucose uptake of skeletal muscle.

It is important to note the constant difference in glucose disposal between $\mathrm{G}$ and $\mathrm{g}$ clamps $(0.3 \mathrm{mmol} /$ min) whatever the hyperinsulinemia level and the pe$\operatorname{riod}(\mathrm{H}$ or $\mathrm{C})$. In other words, the hyperglycemic state as such resulted in a constant non-insulin-mediated glucose uptake. On the basis of studies in calves under hyperglycemia (28), it seems unlikely that glucose urinary losses significantly contribute to non-insulin-mediated glucose disposal, although the phenomena could differ in veal and lactating goats.

The hyperglycemic period did not affect milk yield. This may appear surprising because mammary gland glucose uptake is the most important non-insulin-mediated glucose uptake. However, this lack of increase in milk volume was already observed in lactating ruminants receiving lower doses of glucose either intravenously $(2,13)$ or abomasally (15). Considering that milk lactose is the major osmoregulator of milk volume, we may conclude that glucose utilization for lactose synthesis (43) was not modified in the present experiment. However, hyperglycemia greatly increased glucose availability in all tissues. In that scope, we might, therefore, assume that although glucose uptake by the mammary gland was increased, lactose synthesis or another utilization of glucose within the mammary gland was impaired as observed by Hurtaud et al. (29). In that case, the extracted amount of glucose could be used as an energy source and be oxidized. However, this hypothesis is not clearly supported by literature data. Whole body glucose oxidation was unchanged in lactating cows receiving a long-term glucose infusion at a lower dose $(2,15)$. In lactating goats, on the other hand, the incorporation of glucose carbon into mammary venous $\mathrm{CO}_{2}$ increased (13) without any increase of glucose uptake by the mammary gland. On the basis of work by Griinari et al. (23), it seems unlikely that the mammary gland can synthesize milk and protein at maximum capacity. In the present experiment, the reduction of feed intake led to a decrease in the availability of milk precursors other than glucose, which may have limited milk synthesis. The decrease in essential amino acid availability was probably the key factor to limit milk yield because most essential plasma free amino acids showed a decrease. Accordingly, abomasal glucose infusion only increased milk yield when protein intake was increased in par- 
allel in lactating cows (15). Intravenous glucose during 4-day euglycemic insulin clamps only stimulated milk production when abomasal infusion of protein and amino acids were present (23). Alternatively, it appears from studies in monogastric mammals that hyperglycemia as such greatly stimulates the non-insulin-mediated glucose uptake in skeletal muscle (7).

The hyperglycemic period greatly increased glucose availability but at the same time decreased the feed intake. The reduction of feed intake has already been observed in rats maintained for 3 or 4 days in a state of mild hyperglycemic hyperinsulinemia $(25,36)$. This has also been observed in lactating cows, whose dry matter intake decreased at the end of 4-day hyperinsulinemic euglycemic clamps $(23,39,43)$. This reduction of feed intake clearly reduces the availability of important gluconeogenic substrates (e.g., propionic acid and amino acids absorbed). The associated hyperinsulinemia also results in the inhibition of the gluconeogenic pathway (16). Euglycemic hyperinsulinemia in goats greatly reduces the expression of phosphoenolpyruvate carboxy kinase mRNA in the liver (35). This could explain the decrease in the endogenous glucose appearance rate after acute (19) or 3-day hyperglycemia.

We conclude that increasing glucose supply for a 3 -day period does not induce any insulin resistance in the lactating goat. On the contrary, it improves the insulin-stimulated glucose disposal. Hyperglycemia as such and duration of exposure (3 days) to glucose both participate in this improvement. This enhanced insulin sensitivity might increase the glucose uptake by skeletal muscles, although no evidence of this diversion could be demonstrated from studies on GLUT-4 in crude membranes from the longissimus thoracis muscle.

\section{Perspectives}

Despite the fact that glucose availability is more crucial in lactating ruminants than in adult, nonlactating women or nonlactating rodents, extramammary peripheral metabolism shows a closely similar adaptation to mild short-term hyperglycemia. Because our experiment was performed under amino acid replacement and not like those performed in adults or nonlactating rodents, further studies are needed to analyze the possible effect of amino acid availability. An improved amino acid replacement has to be considered, especially to prevent any decrease of blood free amino acids over the hyperglycemic period. This decrease may have limited milk yield in the present experiment. A better knowledge of the uptake and metabolism of glucose and amino acids in tissues and mammary gland is also needed to understand mechanisms of the effect of hyperglycemia. Studies such as this are useful to control and manipulate high-energy diets for lactating ruminants.

We gratefully acknowledge Dr. G. E. Lobley for expert advice and for guidance in the writing of this manuscript. Our thanks go to Drs. D. Dardevet, C. Obled, Y. Boirie, P. Patureau-Mirand, and L. Mosoni for helpful discussions. We are also grateful to C. Cubizolles and her team for technical assistance and P. Capitan and I. Jicquel for laboratory analyses. M. S. N. Carpenter was responsible for the English proof reading.

\section{REFERENCES}

1. Abe H, Kawakita Y, Miyashige T, Morimatsu M, and Saito M. Comparison of amino acid sequence of the C-terminal domain of insulin-responsive glucose transporter (GLUT4) in livestock mammals. J Vet Med Sci 60: 769-771, 1998.

2. Amaral DM, Veenhuizen JJ, Drackley JK, Cooley MH, McGilliard AD, and Young JW. Metabolism of propionate, glucose, and carbon dioxide as affected by exogenous glucose in dairy cows at energy equilibrium. J Dairy Sci 73: 1244-1255, 1990.

3. Andersen PH, Lund S, Vestergaard H, Junker S, Kahn BB, and Perdersen $\mathbf{O}$. Expression of the major insulin regulatable glucose transporter (GLUT4) in skeletal muscle of non-insulindependent diabetic patients and healthy subjects before and after insulin infusion. J Clin Endocrinol Metab 77: 27-32, 1993.

4. Balage M, Hocquette JF, Graulet B, Ferré P, and Grizard J. Skeletal muscle glucose transporter (GLUT4) protein is decreased in lactating goats. Anim Sci 65: 257-265, 1997.

5. Balage M, Larbaud D, Debras E, Hocquette JF, and Grizard J. Acute hyperinsulinemia fails to change GLUT-4 content in crude membranes from goat skeletal muscles and adipose tissue. Comp Biochem Physiol Part A 120: 425-430, 1998.

6. Balage M, Sornet C, and Grizard J. Insulin receptors binding and kinase activity in liver and skeletal muscles of lactating goats. Am J Physiol Endocrinol Metab 262: E561-E568, 1992.

7. Baron AD, Steinberg H, Brechtel G, and Johnson A. Rate and tissue sites of non-insulin- and insulin-mediated glucose uptake. Am J Physiol Endocrinol Metab 255: E769-E774, 1988.

8. Bauman DE and Elliot JM. Control of nutrient partitioning in lactating ruminants. In: Biochemistry of Lactation. Amsterdam, the Netherlands: Elsevier, 1983, p. 437-468.

9. Bergman EN, Reulein SS, and Corlett RE. Effects of obesity on insulin sensitivity and responsiveness in sheep. Am J Physiol Endocrinol Metab 257: E772-E781, 1989.

10. Boden G. Role of fatty acids in the pathogenesis of insulin resistance and NIDDM. Diabetes 46: 3-10, 1997.

11. Boden G, Ruiz J, Kim CJ, and Chen X. Effects of prolonged glucose infusion on insulin secretion, clearance, and action in normal subjects. Am J Physiol Endocrinol Metab 270: E251E258, 1996.

12. Bourey RE, Karanyl L, James DE, Mueckler M, and Permutt MA. Effect of altered glucose homeostasis on glucose transporter expression in skeletal muscle of the rat. J Clin Invest 86: 542-547, 1990.

13. Chaiyabutr N, Faulkner A, and Peaker M. Effects of exogenous glucose on glucose metabolism in lactating goat in vivo. Br J Nutr 49: 159-165, 1983.

14. Charron MJ and Kahn BB. Divergent molecular mechanisms for insulin-resistant glucose transport in muscle and adipose cells in vivo. J Biol Chem 265: 7994-8000, 1990.

15. Clark JH, Spires HR, Derrig RG, and Bennink MR. Milk production, nitrogen utilization and glucose synthesis in lactating cows infused postruminally with sodium caseinate and glucose. J Nutr 107: 631-644, 1977.

16. Debras E, Grizard J, Aina E, Tesseraud S, Champredon C, and Arnal M. Insulin sensitivity and responsiveness during lactation and dry period in goats. Am J Physiol Endocrinol Metab 256: E295-E302, 1989.

17. Dimitrakoudis D, Ramlal T, Rastogl S, Vranic M, and Klips A. Glycaemia regulates the glucose transporter number in the plasma membrane of rat skeletal muscle. Biochem $J$ 284: 341-348, 1992.

18. Dresner A, Laurent D, Marcucci M, Griffin ME, Dufour S, Cline GW, Slezak LA, Andersen DK, Hundal RS, Rothman DL, Petersen KF, and Shulman GI. Effects of free fatty acids on glucose transport and IRS-1-associated phosphatidylinositol 3-kinase activity. J Clin Invest 103: 253-259, 1999. 
19. Faulkner A. Metabolic responses of pregnant, lactating and control goats to a sustained glucose load. Biochem Soc Trans 17: 1084-1085, 1989.

20. Faulkner A. Metabolic responses to euglycaemic hyperinsulinaemia in lactating and non-lactating sheep in vivo. $J$ Endocrinol 124: 59-66, 1990.

21. Flax H, Matthews DR, Levy JC, Coppack SW, and Turner RC. No glucotoxicity after 53 hours of $60 \mathrm{mmol} / \mathrm{l}$ hyperglycemia in normal man. Diabetologia 34: 573-575, 1991.

22. Gill JL. Design and Analysis of Experiments in the Animal and Medical Sciences. Ames: McGraw-Hill, 1986, vol. I, p. 1-409.

23. Griinari JM, McGuire MA, Dwyer DA, Bauman DE, Barbano DM, and House WA. The role of insulin in the regulation of milk protein synthesis in dairy cows. J Dairy Sci 80: 23612371, 1997.

24. Guinard J, Rulquin H, and Vérité R. Effect of graded levels of duodenal infusions of casein on mammary uptake in lactating cows. 1. Major nutrients. J Dairy Sci 77: 2221-2231, 1994.

25. Hager SR, Jochen AL, and Kalkhoff RK. Insulin resistance in normal rats infused with glucose for $72 \mathrm{~h}$. Am J Physiol Endocrinol Metab Physiol 254: E353-E362, 1991.

26. Hocquette JF, Graulet B, Castiglia-Delavaud C, Bornes F, Lepetit N, and Ferré $\mathbf{P}$. Insulin-sensitive glucose transporter transcript levels in calf muscles assessed by bovine GLUT4 cDNA fragment. Int J Biochem Cell Biol 28: 795-806, 1996.

27. Hocquette JF, Ortigues-Marty I, Pethick DW, Herpin P, and Fernandez $\mathbf{X}$. Nutritional and hormonal regulation of energy metabolism in skeletal muscles of meat-producing animals. Livest Prod Sci 56: 115-143, 1998.

28. Hostettler-Allen RL, Tappy L, and Blum JW. Insulin resistance, hyperglycemia, and glucosuria in intensively milk-fed calves. J Anim Sci 72: 160-173, 1994.

29. Hurtaud $\mathbf{C}$, Lemosquet $\mathbf{S}$, and Rulquin $\mathbf{H}$. Effect of graded duodenal infusions of glucose on milk composition and composition of milk from dairy cows. 2. Diets based on grass silage. $J$ Dairy Sci 83: 2952-2962, 2000.

30. Institut National de la Recherche Agronomique. Ruminant Nutrition: Recommended Allowances and Feed Tables. London: John Libbey Eurotext, 1989, p. 1-389.

31. Kahn BB, Rossetti L, Lodish HF, and Charron MJ. Decreased in vivo glucose uptake but normal expression of GLUT1 and GLUT4 in skeletal muscle of diabetic rats. J Clin Invest 87: 2197-2206, 1991.

32. Kahn SE, Bergman RN, Schwartz MW, Taborsky JR, and Porte D. Short-term hyperglycemia and hyperinsulinemia improve insulin action but do not alter glucose action in normal humans. Am J Physiol Endocrinol Metab 262: E518-E523, 1992.

33. Kreisberg RA, Siegal AM, and Crawford WO. Alanine and gluconeogenesis in man: effect of ethanol. J Clin Endocrinol Metab 34: 876-883, 1972.

34. Laarveld B, Christensen DA, and Brockman RP. The effect of insulin on net metabolism of glucose and amino acids by the bovine mammary gland. Endocrinology 108: 2217-2221, 1981.

35. Larbaud D, Debras E, Taillandier D, Samuels SE, Temparis S, Champredon C, Grizard J, and Attaix D. Euglycemic hyperinsulinemia and hyperaminoacidemia decrease skeletal muscle ubiquitin mRNA in goats. Am J Physiol Endocrinol Metab 271: E505-E512, 1996.

36. Laury MC, Penicaud L, Ktorza A, Benhaiem H, Bihoreau MT, and Picon L. In vivo insulin secretion and action in hyperglycemic rat. Am J Physiol Endocrinol Metab 257: E180E184, 1989.

37. Le Marchand Y, Freychet P, and Jeanrenaud B. Longitudinal study on the establishment of insulin resistance in hypothalamic obese mice. Endocrinology 102: 74-85, 1978.

38. Lemosquet S, Rideau N, Rulquin H, Faverdin P, Simon J, and Vérité R. Effect of a duodenal glucose infusion on the relationship between plasma concentrations of glucose and insulin in dairy cows. J Dairy Sci 80: 2854-2865, 1997.

39. Mackle TR, Dwyer K, Ingvartsen KL, Chouinard PY, Ross DA, and Bauman DE. Effects of insulin and postruminal supply of protein on use of amino acids by the mammary gland for milk protein synthesis. J Dairy Sci 83: 93-105, 2000.
40. Mansoor O, Beaufrere B, Boirie Y, Ralliere C, Taillandier D, Aurousseau E, Schoeffler P, Arnal M, and Attaix D. Increased mRNA levels for components of the lysosomal $\mathrm{Ca}^{2+}$ activated, and ATP-ubiquitin-dependent proteolytic pathways in skeletal muscle from head trauma patients. Proc Natl Acad Sci USA 93: 2714-2718, 1996.

41. Marette A, Dimitrakoudis D, Shi Q, Klip A, and Vranic M. Glucose rapidly decreases plasma membrane GLUT4 content in rat skeletal muscle. Endocrine 10: 13-18, 1999.

42. Mathoo JMR, Qing S, Klip A, and Vranic M. Opposite effects of acute hypoglycemia and acute hyperglycemia on glucose transport and glucose transporters in perfused rat skeletal muscle. Diabetes 48: 1281-1287, 1999.

43. McGuire MA, Griinari JM, Dwyer DA, and Bauman DE. Role of insulin in the regulation of mammary synthesis of fat and protein. J Dairy Sci 78: 816-824, 1995.

44. Metcalf JA and Weekes TEC. Effect of plan nutrition on insulin sensitivity during lactation in the ewe. J Dairy Res 57: 465-478, 1990.

45. Ortigues I, Durand D, and Lefaivre J. Use of para-amino hippuric acid to measure blood flows through portal-drainedviscera, liver and hindquarters in sheep. J Agric Sci 122: 299308, 1994.

46. Pisters PWT, Restifo NP, Cersosimo E, and Brennan MF. The effect of euglycemic hyperinsulinemia and amino acid infusion on regional and whole glucose disposal in man. Metabolism 40: 59-65, 1991.

47. Postic C, Leturque A, Rencurel F, Printz RL, Forest C, Granner DK, and Girard J. The effects of hyperinsulinemia and hyperglycemia on GLUT4 and hexokinase II mRNA and protein in rat skeletal muscle and adipose tissue. Diabetes 42 : 922-929, 1993.

48. Santomauro AT, Boden G, Rocha DM, Santos DM, Ursich MJ, Strassmann PG, and Wajchenberg BL. Overnight lowering of free fatty acids with acipimox improves insulin resistance and glucose tolerance in obese diabetic and nondiabetic subjects. Diabetes 48: 1836-1841, 1999.

49. Strout HV, Vicario PP, Biswas C, Saperstein R, Brady EJ, Pilch PF, and Berger J. Vanadate treatment of streptozotocin diabetic rats restores expression of the insulin-responsive glucose transporter in skeletal muscle. Endocrinology 126: 27282732, 1990.

50. Tauveron I, Debras E, Tesseraud S, Bonnet Y, Thiéblot $\mathbf{P}$, Champredon C, and Grizard J. Metabolic responses to hyperinsulinaemia under glucose-potassium-amino acids clamp in lactating and non-lactating goats. Anim Sci 60: 99-107, 1995.

51. Tesseraud S, Grizard J, Debras E, Papet I, Bonnet Y, Bayle G, and Champredon C. Leucine metabolism in lactating and dry goats: effect of insulin and substrate availability. Am J Physiol Endocrinol Metab 265: E402-E413, 1993.

52. Tesseraud S, Grizard J, Makarski B, Debras E, Bayle G, and Champredon C. Effect of insulin in conjunction with glucose, amino acids and potassium on net metabolism of glucose and amino acids in the goat mammary gland. J Dairy Res 59: 135-149, 1992.

53. Trimble ER, Weir GC, Gjinovci A, AssimacopoulosJeannnet F, Benzi R, and Renold AE. Increased insulin responsiveness in vivo and in vitro consequent to induced hyperinsulinemia in the rat. Diabetes 33: 444-449, 1984.

54. Wardzala LJ, Hirshman M, Pofcher E, Horton ED, Mead PM, Cushman W, and Horton ES. Regulation of glucose utilization in adipose cells and muscle after long-term experimental hyperinsulinemia in rats. J Clin Invest 76: 460-469, 1985.

55. Wieko J and Sherman WR. Boroacetylation of carbohydrates correlations between structure and mass spectral behavior in monoacetylhexose cyclic boronic esters. J Am Chem Soc 98: 7631-7637, 1976.

56. Winer BJ, Brown DR, and Michels KM. Statistical Principles in Experimental Design. New York: McGraw-Hill, 1991, p. 1-1048. 